\title{
THE USE OF RUBBER DAM AMONG CZECH DENTAL PRACTITIONERS
}

\begin{abstract}
Martin Kapitán, Zdeňka Šustová
Charles University in Prague, Faculty of Medicine and University Hospital Hradec Králové, Czech Republic: Department of Dentistry

Summary: Rubber dam is considered an ideal device for tooth isolation. Nevertheless, its usage is quite rare in the Czech Republic. The aim of this study was: firstly, to gather and evaluate information regarding the use of rubber dam by dentists in the Czech Republic and to compare it with other countries; secondly to find out whether there are any influencing factors as to rubber dam usage; and finally to find out frequency of rubber dam use separately in endodontic treatment and in placing fillings of different materials. A questionnaire-based survey was conducted. Dentists filled in the questionnaires during dental conventions, educational events, conferences and congresses. Rubber dam was routinely used by less than eight per cent of the respondents $(n=35)$; less than twenty-two per cent of the respondents $(n=97)$ used rubber dam occasionally, and more than seventy per cent of the respondents $(n=317)$ has never use it. The results showed that rubber dam is not used frequently in the Czech Republic. If rubber dam is used, then it is typically for endodontic treatment or composite fillings. There were several factors with a statistically significant influence on the usage of rubber dam, such as gender, length of professional career, percentage of direct payments, previous experience in using rubber dam, and undergraduate training in rubber dam use.
\end{abstract}

Key words: Frequency of use; Isolation; Rubber dam; Questionnaires; Utilisation

\section{Introduction}

Rubber dam is considered an ideal device for tooth isolation in restorative dentistry and endodontics. In spite of all the recommendations (6) and its wide range of functions, rubber dam has been often overlooked by general dental practitioners $(1,4,8)$.

Many studies have been published dealing with the frequency of rubber dam usage within several countries. These studies showed that the frequency of rubber dam usage varies and is not dependent on the socio-economical level of the country or the year of the study. The declared portion of rubber dam users varies greatly, ranging from $3 \%$ to $90 \%$ $(2,3,4,9,10,11,17,18,21,22)$. The portion of rubber dam non-users is from $44.5 \%$ to $95 \%(9,10,15,16,17$, $18,22)$. No similar study about rubber dam usage has been performed in the Czech Republic yet.

The aim of this study was firstly to gather and evaluate information regarding the use of rubber dam by dentists in the Czech Republic and to compare it with other countries, secondly to find out whether there are any influencing factors as to rubber dam usage, and finally to find out frequency of rubber dam use separately in endodontic treatment and in placing fillings of different materials.

\section{Materials and Methods}

A questionnaire-based survey was chosen as the study design. The questionnaire was created based on surveys in other countries $(9,13,14,22)$. A pilot survey was taken first. The questionnaire, along with an addressed and stamped return envelope, was sent by post to 100 members of the Regional Dental Chamber in Hradec Kralove. The mail charges were covered by the Department of Dentistry in Hradec Kralove. The response rate was 36 per cent. This small amount of questionnaires did not allow us to do relevant statistical analysis. Due to the low response rate, we decided to simplify the questionnaire and to change the process of distributing and collecting the questionnaires. The final version of the questionnaire was translated and is shown in Figure 1. The survey was conducted from autumn 2009 to spring 2010. We distributed 700 questionnaires during Czech Dental Chamber conventions and continuing educational events organized by the Chamber and/or by the Department of Dentistry in Hradec Kralove, as well as during other dental conferences and congresses. The participation of the dentists was voluntary and restricted to general dental practitioners. Completed questionnaires were collected immediately, sent by post by respondents or delivered personally by organisers.

The collected data were statistically analysed using the Microsoft Excel 2003 programme. The chi-square test was used to assess the influence of various factors on the frequency of rubber dam use, the significance threshold was set at $\mathrm{p}=0.05$. If the questionnaire was not filled completely, it was not excluded as a whole, but only the answered questions were taken into consideration in statistical analysis. 


\begin{tabular}{|c|c|c|}
\hline & \multicolumn{2}{|l|}{$\begin{array}{l}\text { Gender } \\
\text { Man } \\
\text { Woman }\end{array}$} \\
\hline $\begin{array}{l}\text { a. } \\
\text { a. } \\
\text { b. } \\
\text { c. } \\
\text { d. } \\
\text { e. }\end{array}$ & $\begin{array}{l}\text { Length of professional career } \\
\text { Less than } 5 \text { years } \\
6-15 \text { years } \\
16-25 \text { years } \\
26-35 \text { years } \\
36 \text { years and more } \\
\end{array}$ & $\begin{array}{ll}\text { 3. } & \text { Size of municipality } \\
\text { a. } & \text { Less than } 10,000 \text { citizens } \\
\text { b. } & 10,000-20,000 \text { citizens } \\
\text { c. } & 20,000-40,000 \text { citizens } \\
\text { d. } & 40,000-90,000 \text { citizens } \\
\text { e. } & 90,000 \text { citizens and more }\end{array}$ \\
\hline $\begin{array}{l}\text { 4. } \\
\text { a. } \\
\text { b. } \\
\text { c. } \\
\text { d. } \\
\text { e. } \\
\text { f. }\end{array}$ & \multicolumn{2}{|c|}{$\begin{array}{l}\text { School of graduation } \\
\text { Charles University in Prague, First Faculty of Medicine in Prague } \\
\text { Charles University in Prague, Faculty of Medicine in Pilsen } \\
\text { Charles University in Prague, Faculty of Medicine in Hradec Kralove } \\
\text { Palacky University in Olomouc, Faculty of Medicine and Dentistry } \\
\text { Masaryk University in Brno, Faculty of Medicine } \\
\text { Other }\end{array}$} \\
\hline $\begin{array}{l}\text { 5. } \\
\text { a. } \\
\text { b. } \\
\text { c. }\end{array}$ & $\begin{array}{l}\text { What is the percentage of direct payments i } \\
\text { Less than } 15 \% \\
15-39 \% \\
40-59 \%\end{array}$ & $\begin{array}{ll}\text { lental office? } \\
\text { d. } \quad 60-84 \% \\
\text { e. } \quad 85 \% \text { and more } \\
\text { f. } \quad \text { Not reported }\end{array}$ \\
\hline $\begin{array}{l}\text { 6. } \\
\text { a. } \\
\text { b. }\end{array}$ & $\begin{array}{l}\text { Do you have your own practical experience } \\
\text { with rubber dam? } \\
\text { Yes } \\
\text { No }\end{array}$ & $\begin{array}{l}\text { 7. Did you receive training in rubber dam } \\
\text { placing during your undergraduate studies? } \\
\text { a. Yes } \\
\text { b. No }\end{array}$ \\
\hline & $\begin{array}{l}\text { Do you use rubber dam? } \\
\text { Yes, regularly } \\
\text { Yes, occasionally } \\
\text { No }\end{array}$ & \\
\hline $\begin{array}{l}9 . \\
\text { a. } \\
\text { b. } \\
\text { c. }\end{array}$ & $\begin{array}{l}\text { Do you use rubber dam during the placing } \\
\text { of amalgam fillings? } \\
\text { Yes, regularly } \\
\text { Yes, occasionally } \\
\text { No }\end{array}$ & $\begin{array}{l}\text { 10. Do you use rubber dam during the placing } \\
\text { of composite resin fillings? } \\
\text { a. Yes, regularly } \\
\text { b. Yes, occasionally } \\
\text { c. No }\end{array}$ \\
\hline $\begin{array}{l}11 . \\
\text { a. } \\
\text { b. } \\
\text { c. }\end{array}$ & $\begin{array}{l}\text { Do you use rubber dam during the placing } \\
\text { of glassionomer cement fillings? } \\
\text { Yes, regularly } \\
\text { Yes, occasionally } \\
\text { No }\end{array}$ & $\begin{array}{l}\text { 12. Do you use rubber dam during root canal } \\
\text { treatment? } \\
\text { a. Yes, regularly } \\
\text { b. Yes, occasionally } \\
\text { c. No }\end{array}$ \\
\hline & $\begin{array}{l}\text { Do you use rubber dam in children } \\
\text { (up to } 15 \text { years of age)? } \\
\text { Yes } \\
\text { No }\end{array}$ & $\begin{array}{l}\text { 14. Would you use rubber dam more often, if its } \\
\text { use was covered by health insurance? } \\
\text { a. Yes } \\
\text { b. No } \\
\text { c. I don't know }\end{array}$ \\
\hline
\end{tabular}

Fig. 1: Questionnaire

\section{Results}

In all, 450 out of 700 questionnaires were collected from the respondents and statistically analysed. The response rate was sixty-four per cent. Demografic and background data of the respondents are given in Table 1 . About fifty per cent of the respondents $(n=223)$ had practical experience in the use of rubber dam; thirty-two per cent of the respondents
( $n=142)$ received training in rubber dam placement during their undergraduate studies. Rubber dam was routinely used by less than eight per cent of the respondents $(n=35)$; less than twenty-two per cent of the respondents $(n=97)$ used rubber dam occasionally, and more than seventy per cent of the respondents $(n=317)$ never used rubber dam. Usage of rubber dam in placing fillings of different materials and in endodontic treatment is shown in Table 2. 
Tab. 1: Demografic and background data of the respondents

\begin{tabular}{|c|c|c|}
\hline Gender & No & $\%$ \\
\hline Man & 294 & 66 \\
\hline Woman & 153 & 34 \\
\hline Total & 447 & 100 \\
\hline \multicolumn{3}{|l|}{ Length of career (years) } \\
\hline$<5$ & 162 & 36 \\
\hline $6-15$ & 72 & 16 \\
\hline $16-25$ & 62 & 14 \\
\hline $26-35$ & 122 & 27 \\
\hline$>36$ & 32 & 7 \\
\hline Total & 450 & 100 \\
\hline \multicolumn{3}{|l|}{ Size of municipality (citizens) } \\
\hline$<10,000$ & 99 & 22 \\
\hline $10,000-20,000$ & 56 & 12 \\
\hline $20,000-40,000$ & 63 & 14 \\
\hline $40,000-90,000$ & 44 & 10 \\
\hline$>90,000$ & 188 & 42 \\
\hline Total & 450 & 100 \\
\hline \multicolumn{3}{|l|}{ Percentage of direct payments } \\
\hline$<15 \%$ & 69 & 15 \\
\hline $15 \%-39 \%$ & 206 & 46 \\
\hline $40 \%-59 \%$ & 78 & 17 \\
\hline $60 \%-84 \%$ & 45 & 10 \\
\hline $85 \%$ or more & 24 & 5 \\
\hline Not reported & 28 & 6 \\
\hline Total & 450 & 99 \\
\hline \multicolumn{3}{|l|}{ School of graduation } \\
\hline $\begin{array}{l}\text { Charles University in Prague } \\
\text { First Faculty of Medicine }\end{array}$ & 99 & 22 \\
\hline $\begin{array}{l}\text { Charles University in Prague } \\
\text { Faculty of Medicine in Pilsen }\end{array}$ & 41 & 9 \\
\hline $\begin{array}{l}\text { Charles University in Prague } \\
\text { Faculty of Medicine } \\
\text { in Hradec Kralove }\end{array}$ & 139 & 31 \\
\hline $\begin{array}{l}\text { Palacky University in Olomouc, } \\
\text { Faculty of Medicine and Dentistry }\end{array}$ & 101 & 22 \\
\hline $\begin{array}{l}\text { Masaryk University in Brno, } \\
\text { Faculty of Medicine }\end{array}$ & 58 & 13 \\
\hline Other & 12 & 3 \\
\hline Total & 450 & 100 \\
\hline
\end{tabular}

Gender, length of professional career, percentage of direct payments, experience in using rubber dam and undergraduate rubber dam training presented statistically significant influence on the frequency of rubber dam usage. Tables 3, 4 and 5 show influence of gender, length of career and percentage of direct payments on rubber dam usage. Dentists with experience in rubber dam are more likely to use it than those without any rubber dam experience (chisquare test, p-value 0). Dentists who were trained in rubber dam placing are more likely to use rubber dam than those
Tab. 2: Reported use of rubber dam in different materials and treatment

\begin{tabular}{|l|c|c|c|}
\hline $\begin{array}{l}\text { Material/ } \\
\text { treatment }\end{array}$ & $\begin{array}{c}\text { Regularly } \\
\mathrm{n}(\%)\end{array}$ & $\begin{array}{c}\text { Occasion- } \\
\text { ally n (\%) }\end{array}$ & $\begin{array}{c}\text { Never } \\
\mathrm{n}(\%)\end{array}$ \\
\hline Amalgam & $10(2)$ & $43(10)$ & $392(88)$ \\
\hline Composite resin & $39(9)$ & $100(22)$ & $309(69)$ \\
\hline $\begin{array}{l}\text { Glassionomer } \\
\text { cement }\end{array}$ & $16(4)$ & $64(14)$ & $366(82)$ \\
\hline $\begin{array}{l}\text { Root canal } \\
\text { treatment }\end{array}$ & $42(9)$ & $76(17)$ & $329(74)$ \\
\hline
\end{tabular}

Tab. 3: Influence of dentist's gender on usage of rubber dam

\begin{tabular}{|l|c|c|c|}
\hline Gender & $\begin{array}{c}\text { Regularly } \\
\text { n (\%) }\end{array}$ & $\begin{array}{c}\text { Occasion- } \\
\text { ally n (\%) }\end{array}$ & $\begin{array}{c}\text { Never } \\
\text { n (\%) }\end{array}$ \\
\hline Men & $17(11)$ & $41(27)$ & $94(62)$ \\
\hline Women & $18(6)$ & $56(19)$ & $220(75)$ \\
\hline Total & $35(8)$ & $97(22)$ & $314(70)$ \\
\hline
\end{tabular}

Usage of rubber dam statistically significantly differes according to dentist's gender (chi-square test, p-value 0.013799). Compared with the whole sample, there are more regular or occasional users in the group of men and more nonusers in the group of women.

Tab. 4: Influence of career length on usage of rubber dam

\begin{tabular}{|l|c|c|c|}
\hline $\begin{array}{l}\text { Length of } \\
\text { career (years) }\end{array}$ & $\begin{array}{c}\text { Regularly } \\
\text { n (\%) }\end{array}$ & $\begin{array}{c}\text { Occasion- } \\
\text { ally n (\%) }\end{array}$ & $\begin{array}{c}\text { Never } \\
\text { n (\%) }\end{array}$ \\
\hline$<15$ & $29(12)$ & $48(21)$ & $156(67)$ \\
\hline$>15$ & $6(3)$ & $49(23)$ & $161(75)$ \\
\hline Total & $35(8)$ & $97(22)$ & $317(71)$ \\
\hline
\end{tabular}

Dentists with shorter career are more likely regular users whereas dentists with longer career are more likely rubber dam nonusers (chi-square test, p-value 0.00381).

Tab. 5: Influence of percentage of direct payments on usage of rubber dam

\begin{tabular}{|l|r|r|r|}
\hline $\begin{array}{l}\text { Percentage of } \\
\text { direct payments }\end{array}$ & $\begin{array}{c}\text { Regularly } \\
\mathrm{n}(\%)\end{array}$ & $\begin{array}{c}\text { Occasion- } \\
\text { ally n (\%) }\end{array}$ & $\begin{array}{c}\text { Never } \\
\mathrm{n}(\%)\end{array}$ \\
\hline$<15 \%$ & $1(1)$ & $17(25)$ & $51(74)$ \\
\hline $15 \%-39 \%$ & $3(1)$ & $32(16)$ & $171(83)$ \\
\hline $40 \%-59 \%$ & $5(6)$ & $18(23)$ & $55(71)$ \\
\hline $60 \%-84 \%$ & $13(30)$ & $13(30)$ & $18(41)$ \\
\hline $85 \%$ or more & $11(46)$ & $9(38)$ & $4(17)$ \\
\hline Not reported & $2(7)$ & $8(29)$ & $18(64)$ \\
\hline Total & $35(8)$ & $97(22)$ & $317(71)$ \\
\hline
\end{tabular}

Dentists with higher percentage of direct payments are more likely regular users whereas dentists with lower percentage of direct payments are more likely rubber dam nonusers (chi-square test, p-value 0). 
Tab. 6: Usage of rubber dam in children

\begin{tabular}{|l|c|c|}
\hline \multirow{2}{*}{$\begin{array}{l}\text { General usage } \\
\text { of rubber dam }\end{array}$} & \multicolumn{2}{|c|}{ Usage of rubber dam in children } \\
\cline { 2 - 3 } & $\begin{array}{c}\text { Yes } \\
\mathrm{n}(\%)\end{array}$ & $\begin{array}{c}\text { No } \\
\mathrm{n}(\%)\end{array}$ \\
\hline Regular users & $15(44)$ & $19(56)$ \\
\hline Occasional users & $2(2)$ & $93(98)$ \\
\hline Nonusers & $0(0)$ & $315(100)$ \\
\hline Total & $17(4)$ & $428(96)$ \\
\hline
\end{tabular}

Tab. 7: The opinion about eventual change in rubber dam usage, if it was covered by health insurance

\begin{tabular}{|c|c|c|c|}
\hline \multicolumn{4}{|c|}{$\begin{array}{l}\text { Would you use rubber dam more often, if its use was } \\
\text { covered by health insurance? }\end{array}$} \\
\hline & $\begin{array}{c}\text { Yes } \\
\mathrm{n}(\%)\end{array}$ & $\begin{array}{l}\text { No } \\
\mathrm{n}(\%)\end{array}$ & $\begin{array}{l}\text { I don't know } \\
n(\%)\end{array}$ \\
\hline Regular users & $10(29)$ & $22(63)$ & $3(9)$ \\
\hline Occasional users & $50(52)$ & $25(26)$ & $22(23)$ \\
\hline Nonusers & $115(37)$ & $56(18)$ & $144(46)$ \\
\hline Total & $175(39)$ & $103(23)$ & $169(38)$ \\
\hline
\end{tabular}

The opinion of respondents about eventual change in rubber dam usage, if it was covered by health insurance, differs significantly according to the usage of rubber dam (chi-square test, p-value $<0.001$ ). Most frequent answer in each group is in bold.

without any undergraduate rubber dam training (chi-square test, p-value 0.00757).

No statistically significant dependence was detected between the frequency of rubber dam use and the size of the municipality in which the dentist worked, nor between the frequency of rubber dam usage and the school from which the dentist graduated.

Rubber dam usage in children up to 15 years of age is shown in Table 6 . The opinion of respondents concerning an eventual change in rubber dam usage, if it was covered by health insurance, is given in Table 7.

\section{Discussion}

The distribution of dental practitioners in the groups with respect to gender, size of municipality, and percentage of direct payments was in accordance with the average dentist population in the Czech Republic as published in the Czech Dental Chamber Annual report 2009 (5). The percentage of dental practitioners with careers spanning up to 5 years and graduates of the Faculty of Medicine in Hradec Kralove in the sample was bigger than in the whole population. The reason for this was that a significant portion of the questionnaires had been distributed in courses organized by the Czech Dental Chamber for young dentists up to 3 years after graduation. Another significant portion of the questionnaires had been distributed in the region of Hradec Kralove, where most of dentists are graduates of the Faculty of Medicine in Hradec Kralove. As the graduates of all faculties in the Czech Republic have passed very similar curricula, we did not try to achieve the same spectrum of graduates in our sample as in the whole population.

The results of this study show that rubber dam is used in patient treatment regularly or occasionally by less than thirty per cent of our respondents, while more than seventy per cent of the respondents have never used rubber dam. This level of rubber dam usage is better than in Belgium (18), Cameroun (16), Denmark (4) and Saudi Arabia (2); similar to usage in the United Kingdom $(15,22)$, Jordan (3), Nigeria (21) and Lithuania (17); but worse than in the United Kingdom (10), New Zealand (12), the USA (9) and Sweden (11). These studies were mainly taken among general dental practitioners. The smallest samples were in Cameroun - 33 (16) and Nigeria - 100 (21). The largest samples were in Lithuania - 1532 (17) and Belgium - 1143 (18). The number of respondents in our study was sufficient to do regular statistical analysis.

Dentists who received rubber dam training during undergraduate studies use rubber dam more often. However, only twelve per cent $(n=17)$ of them use rubber dam regularly. This finding indicates that the most of the dentists who have been trained in using rubber dam discontinued use once they began to practise dentistry. This is consistent with the results of study of Mala et al. (14), who showed that sixtytwo per cent of students believed that their overall usage of rubber dam would have decreased when starting their own chair-side practice.

Rubber dam is used more frequently by dentists who have been practising for a shorter length of time. This is in accordance with the results of Whitworth et al. (22) and Peciuliene et al. (17), but in contradiction to results of Jenkins et al. (10). Two factors could contribute in the Czech Republic: first, rubber dam was virtually unavailable before 1989; second, the use of rubber dam has been implemented into the undergraduate dentistry curriculum relatively recently. In our faculty, systematic teaching in rubber dam isolation has begun during the academic year 2006/2007.

Rubber dam is mostly used for root canal treatment and for the placement of composite fillings. This finding is similar to studies from other countries $(9,13)$.

The use of rubber dam in the treatment of children is limited appreciably by the children's poor cooperation (19). More than half of the regular rubber dam users do not use it when treating children.

The frequency of rubber dam usage increases significantly with increasing percentage of direct payments. Dentists are forced or motivated more to use rubber dam as a quality standard method of operation field isolation in treatment, which is not covered by health insurance and is fully paid by patients.

We suppose that the real frequency of rubber dam use by all dentists in the Czech Republic might be lower than what 
we found in this study. This hypothesis is supported by several factors. First, a significant amount of the questionnaires was obtained from younger dentists, who, as we stated, use rubber dam more frequently than older colleagues. Second, probably more important, a significant number of the questionnaires were filled in by training course and workshop participants and exhibition visitors; and in fact, dentists who attend such events are generally more committed to their profession and more interested in further education, and so the probability that they use rubber dam is higher than in the overall dental practitioners population (12). Third, many dentists, mostly older refused to fill in the questionnaire simply on the grounds that it concerned rubber dam, which they themselves have never used.

Barriers for the use of rubber dam apparently include lack of experience, underestimation of its benefits and a lack of motivation $(1,7,13,19)$. Another reason is that the amount of time required to place rubber dam is often overestimated $(1,7,15)$. Furthermore, dentists are often concerned that patients will not tolerate rubber dam $(1,19)$.

In the experience of regular rubber dam users, placing rubber dam in routine circumstances does not require more than a minute or two of additional time. If instructed properly, most patients tolerate rubber dam very well; many of them even find treatment with rubber dam more comfortable and bearable $(7,20)$.

\section{Conclusions}

- Rubber dam is not widespread or routinely used in the Czech Republic, which is similar to practices in other countries.

- The usage of rubber dam is more frequent in younger dental practitioners, in dentists with a higher percentage of direct payments and with experience in using rubber dam, and in those who received undergraduate training in work with rubber dam.

- Rubber dam is mostly used for endodontic treatment and for the placement of composite fillings.

\section{Acknowledgements}

The authors would like to thank Mrs. Jana Pochvalovska from the Italdent company for help with distribution of questionnaires; Mr. Josef Bukac, M.Sc., MS, Ph.D. from the Department of Medical Biophysics, Faculty of Medicine in Hradec Kralove, Charles University in Prague for help with statistical analysis; Mr. Matthew Shane Renfro, B.A. from the Department of Languages, Faculty of Medicine in Hradec Kralove, Charles University in Prague for language review of the manuscript.

The authors do not declare any conflict of interest.

\section{References}

1. Ahmad IA. Rubber dam usage for endodontic treatment: A review. International Endodontic Journal 2009; 42: 963-72.

2. Al-Fouzan KS. A survey of root canal treatment of molar teeth by general dental practitioners in private practice in Saudi Arabia. Saudi Dental Journal 2010; 22: $113-7$.

3. Al-Omari MA, Al-Dwairi ZN. Compliance with infection control programs in private dental clinics in Jordan. Journal of Dental Education 2005; 69: 693-8.

4. Bjorndal L, Reit C. The adoption of new endodontic technology amongst Danish general dental practitioners. International Endodontic Journal 2005; 38: 52-8.

5. Czech Dental Chamber. Annual report 2009. Prague, 2010 (released March 2010). (Accessed on June 1, 2011 at http://www.dent.cz/img_data/file/2010 /Rocenka 2009 na\%20web komplet.pdf).

6. European Society of Endodontology. Quality guidelines for endodontic treatment: consensus report of the European Society of Endodontology. International Endodontic Journal 2006; 39: 921-30.

7. Filipović J, Jukić S, Miletić I, Pavelić B, Malčić A, Anić I. Patient's Attitude to Rubber Dam Use. Acta Stomatologica Croatica 2004; 38: 319-22.

8. Gergely EJ. Desmond Greer Walker Award. Rubber dam acceptance. British Dental Journal 1989; 167: 249-52.

9. Hill EE, Rubel BS Do Dental Educators Need to Improve Their Approach to Teaching Rubber Dam Use? Journal of Dental Education 2008; 72: 1177-81.

10. Jenkins SM, Hayes SJ, Dummer PMH. A study of endodontic treatment carried out in dental practice within the UK. International Endodontic Journal 2001; 34: $16-22$.

11. Koch M, Eriksson HG, Axelsson S, Tegelberg A.. Effect of educational intervention on adoption of new endodontic technology by general dental practitioners: a questionnaire survey. International Endodontic Journal 2009; 42: 313-21.

12. Koshy S, Chandler NP. Use of rubber dam and its association with other endodontic procedures in New Zealand. New Zealand Dental Journal 2002; 98: 12-6.

13. Lynch CD, McConnell RJ. Attitudes and use of rubber dam by Irish general dental practitioners. International Endodontic Journal 2007; 40: 427-32.

14. Mala S, Lynch CD, Burke FM, Dummer PMH. Attitudes of final year dental students to the use of rubber dam. International Endodontic Journal 2009; 42: $632-8$.

15. Marshall K, Page J. The use of rubber dam in the UK. A survey. British Dental Journal 1990; 169: 286-91.

16. Onana J, Ngongang A. Hygiene and methods of decontamination, disinfection and sterilization in dental offices in Yaounde. Odonto-stomatologie Tropicale 2002; 25: $45-51$.

17. Peciuliene V, Rimkuviene J, Aleksejuniene J, Haapasalo M, Drukteinis S, Maneliene R. Technical aspects of endodontic treatment procedures among Lithuanian general dental practitioners. Stomatologija Baltic Dental and Maxillofacial Journal 2010; $12: 42-50$.

18. Slaus G, Bottenberg P. A survey of endodontic practice amongst Flemish dentists. International Endodontic Journal 2002; 35: 759-67.

19. Soldani F, Foley J. An assessment of rubber dam usage amongst specialists in paediatric dentistry practising within the UK. International Journal of Paediatric Dentistry 2007; 17: 50-6.

20. Stewardson DA, McHugh ES. Patients' attitudes to rubber dam. International Endodontic Journal 2002; 35: 812-9.

21. Udoye CI, Jafarzadeh H. Rubber dam use among a subpopulation of Nigerian dentists. Journal of Oral Science 2010; 52: 245-9.

22. Whitworth JM, Seccombe GV, Shoker K, Steele JG. Use of rubber dam and irrigan selection in UK general dental practice. International Endodontic Journal 2000; 33: $435-41$.

\section{Corresponding author:}

Martin Kapitán, M.D., Department of Dentistry, Faculty of Medicine in Hradec Kralove, Charles University in Prague and University Hospital in Hradec Králové, Czech Republic; e-mail: martin.kapitan@seznam.cz 